\title{
PENGEMBANGAN MEDIA PEMBELAJARAN BERBASIS TEKNOLOGI APLIKASI AUGMENTED REALITY DALAM MENINGKATKAN PROSES PENGAJARAN SISWA SEKOLAH DASAR
}

\author{
Usmaedi $^{1}$, Putri Yuniar Fatmawati ${ }^{2}$, Aprian Karisman ${ }^{3}$ \\ 1-2STKIP Setiabudhi, ${ }^{3}$ Sekolah Tinggi Teknik Multimedia Cendikia Abditama \\ 1usmaedikentlee@gmail.com
}

\begin{abstract}
The low performance of elementary school students in ICT-based learning media, one of which is due to the ineffective learning media used by teachers in the classroom. Augmented reality is a technology that combines the digital world with the real-time user environment. Augmented reality uses an existing environment in the real world and then adds new information on top of it. Current Augmented Reality research deals with the use of video images that appear digitally and then added with the addition of computer-generated graphics. Elementary school (SD) students who are the object of this research are one of the public elementary schools in Lebak-Banten Regency. This is done, among other things, by always updating the media that has been processed in the process. Augmented reality application development as a learning media to support the processing process in elementary schools is a research conducted to support the readiness of educational institutions in ensuring the quality of education by providing interactive learning media based on Augmented reality technology. In this research, the researcher took one of the subjects that would be the research material, namely English. The purpose of this research is to be able to produce a media based on Augmented reality technology that is interactive and easy to use, so that the process will be more interesting and easy to implement, and can encourage educational institutions to take advantage of Augmented reality technology as an interactive and fun learning medium.
\end{abstract}

Keywords: Augmented Reality, Learning Media, Teaching

\begin{abstract}
ABSTRAK
Rendahnya performa siswa sekolah dasar dalam media pembelajaran berbasis ICT, salah satunya disebabkan oleh kurang efektifnya media pembelajaran yang digunakan oleh guru di kelas. Augmented reality merupakan teknologi yang menggabungkan dunia digital dengan lingkungan pengguna secara realtime. Augmented reality ini menggunakan lingkungan yang ada di dunia nyata dan kemudian menambahkan informasi baru di atasnya. Penelitian Augmented reality saat ini berkaitan dengan penggunaan citra video yang diproses secara digital lalu ditambah dengan penambahan grafik yang dihasilkan komputer. Siswa Sekolah Dasar (SD) yang menjadi objek penelitian ini merupakan salah satu sekolah dasar negeri di Kabupaten Lebak-Banten. Hal ini antara lain dilakukan dengan selalu memperbaharui media pengajaran yang digunakan dalam proses pengajaran. Pengembangan Aplikasi Augmented reality sebagai media pembelajaran untuk menunjang proses pengajaran pada Sekolah Dasar adalah penelitian yang dilakukan untuk menunjang kesiapan lembaga pendidikan dalam menjamin kualitas pendidikan dengan menyediakan media pembelajaran interaktif berbasis teknologi Augmented reality. Pada penelitian kali ini peneliti mengambil salah satu mata pelajaran yang akan menjadi bahan penelitian yaitu mata pelajaran bahasa inggris. Tujuan dari penelitian ini adalah dapat menghasilkan suatu media pengajaran berbasis teknologi Augmented reality yang interaktif dan mudah digunakan, sehingga proses pengajaran akan lebih menarik dan mudah dipahami, serta dapat mendorong lembaga pendidikan untuk memanfaatkan teknologi Augmented reality sebagai media pembelajaran yang interaktif dan menyenangkan.
\end{abstract}

Kata Kunci: Augmented Reality, Media Pembelajaran, Pengajaran

Submitted Nov 11, 2020 | Revised Nov 26, 2020 | Accepted Nov 30, 2020

\section{Pendahuluan}

Saat ini, pembelajaran berbasis digital menggunakan media Powerpoint sudah dapat digunakan untuk mempresentasikan apa yang ingin kita sampaikan kepada siswa. Menyusul kemudian media pembelajaran berbasis buku digital (e-book) yang dikombinasikan dengan media pembelajaran berbasis 
web berupa LMS (Learning Management System), menjadi solusi kebutuhan blended learning yang sampai sekarang juga masih banyak dimanfaatkan oleh guru/dosen.

Sejalan dengan meluasnya penggunaan gadget/smartphone di kalangan guru dan siswa, teknologi pembelajaran pun lantas berkembang ke arah media berbasis mobile Android yang memaksa para guru berlomba mengembangkan berbagai aplikasi pembelajaran berbasis Android dengan konten berbasis multimedia yang dapat digunakan oleh siswa untuk belajar di kelas maupun di luar kelas. Tak hanya itu, aplikasi pembelajaran berbasis Android pun saat ini mulai berkembang ke arah teknologi Angmented reality (AR) yang menggabungkan benda maya 2 dimensi dan ataupun 3 dimensi ke dalam sebuah lingkungan 3 dimensi dan memproyeksikan benda-benda maya tersebut secara nyata. Kombinasi dari teknologi ini memungkinkan penggabungan secara realtime antara konten virtual pada komputer dengan tampilan secara langsung pada video.

Metode pembelajaran yang digunakan untuk mendukung proses kegiatan belajar mengajar di Sekolah Dasar saat ini masih menggunakan media buku, LKS, dan menggunakan bahan praktek alat peraga. Sedangkan proses pembelajaran yang ada saat ini guru menulis dan menerangkan kemudian siswa mencatat materi yang ditulis oleh guru. Alat peraga yang hanya tersedia 1 unit sedangkan jumlah siswa di kelas kurang lebih ada 30 anak. Tentu hal ini akan menimbulkan suasana yang kurang mendukung bagi siswa-siswi pada saat proses belajar mengajar berlangsung sehingga pemahaman atau penguasaan materi yang di dapat kurang maksimal. Oleh sebab itu, maka sangat penting untuk memanfaatkan teknologi Augmented reality yang mampu merealisasikan dunia virtual ke dunia nyata, dapat mengubah objek-objek tersebut menjadi objek 3D, sehingga metode pembelajaran tidaklah monoton dan penguna jadi terpacu untuk mengetahuinya lebih lanjut. Pemanfaatan Augmented reality pada proses pembelajaran merupakan upaya yang dilakukan untuk mengkorelasikan pembelajaran dengan teknologi yang berkembang.

Tujuan pembelajaran dengan memanfaatkan teknologi Augmented reality guna mendukung proses belajar mengajar khususnya di Sekolah Dasar sehingga proses pengajaran akan lebih interktif dan materi pelajaran mudah dipahami oleh siswa. Dengan menggabungkan Augmented reality ke dalam proses pembelajaran, maka diharapkan akan memberikan pengalaman belajar kepada siswa tentang konsep atau gagasan abstrak yang mungkin sulit dipahami oleh siswa.utama dari dilakukannya penelitian ini adalah untuk membuat aplikasi media.

Realitas tertambah, atau dikenal dengan singkatan bahasa inggrisnya AR (augmented reality), adalah teknologi yang menggabungakn benda maya dua dimensi dan atupun tiga diemensi ke dalam sebuah lingkungan nyata tiga dimensi lalu memoroyeksikan benda benda maya tersebut dalam waktu nyata. Tidak seperti realitas maya yang sepenuhnya menggantikan kenyataan, realitas tertambah sekadar menambahkan atau melengkapi kenyataan. Bendabenda maya menampilkan informasi yang tidak dapat diterima oleh pengguna dengan inderanya sendiri. Hal ini membuat realitas tertambah sesuai sebagai alat untuk membantu persepsi dan interaksi penggunanya dengan dunia nyata. Informasi yang ditampilkan oleh benda maya membantu pengguna melaksanakan kegiatan-kegiatan dalam dunia nyata. Augmented reality adalah sebagai penggabungan benda-benda nyata dan mayadilingkungannyata, berjalan secara interaktif dalam waktu nyata, dan terdapat integrasi antarbenda dalam tiga dimensi, yaitu benda maya terintegrasi dalam dunia nyata. Penggabungan benda nyata dan maya dimungkinkan dengan teknologi tampilan yang sesuai, interaktivitas dimungkinkan melalui perangkat-perangkat input tertentu, dan integrasi yang baik memerlukan penjejakan yang efektif (Hamalik, 2001).

Riset Augmented reality bertujuan untuk mengembangkan teknologi yang memperbolehkan penggabungan secara real-time terhadap digital content yang dibuat oleh komputer dengan dunia nyata. Augmented reality memperbolehkan pengguna melihat objek maya dua dimensi atau tiga dimensi yang diproyeksikan terhadap dunia nyata. Teknologi AR ini dapat menyisipkan suatu informasi tertentu ke dalam dunia maya dan menampilkannya di dunia nyata dengan bantuan perlengkapan seperti webcam, komputer, HP Android, maupun kacamata khusus. User ataupun pengguna di dalam dunia nyata tidak 
dapat melihato bjek maya dengan mata telanjang, untuk mengidentifikasi objek dibutuhkan perantara berupa komputer dan kamera yang nantinya akan menyisipkan objek maya ke dalam dunia nyata.

Tujuan dari AR adalah mengambil dunia nyata sebagai dasar dengan menggabungkan beberapa teknologi virtual dan menambahkan data konstektual agar pemahaman manusia sebagai penggunanya menjadi semakin jelas (Suprapto, et al., 2018; Laksono, 2018; Suciliyana, 2020). Data konstektual ini dapat berupa komentar audio, data lokasi, konteks sejarah, atau dalam bentuk lainnya. Pada saat ini, AR telah banyak digunakan dalam berbagai bidang seperti kedokteran, militer, manufaktur, hiburan, museum, game pendidikan, pendidikan, dan lain-lain.

Sistem Augmented reality bekerja berdasarkan deteksi citra dan citra yang digunakan adalah marker (Adami \& Budihartanti, 2016; Ginting, et al., 2017; Laswi \& Andryanto, 2018). Augmented reality merupakan integrasi elemen elemen digital yang ditambahkan ke dalam dunia nyata secara realtime dan mengikuti keadaan lingkungan yang ada di dunia nyata. Berdasarkan Gambar 1, berikut prinsip kerja augmented reality : Camera yang telah dikalibrasi akan mendeteksi marker yang diberikan, kemudian setelah mengenali dan menandai pola marker, webcam akan melakukan perhitungan apakah marker sesuai dengan database yang dimiliki. Bila tidak, maka informasi marker tidak akan diolah, tetapi bila sesuai maka informasi marker akan digunakan untuk me-render dan menampilkan objek 3D atau animasi yang telah dibuat sebelumnya (Mario, 2013).

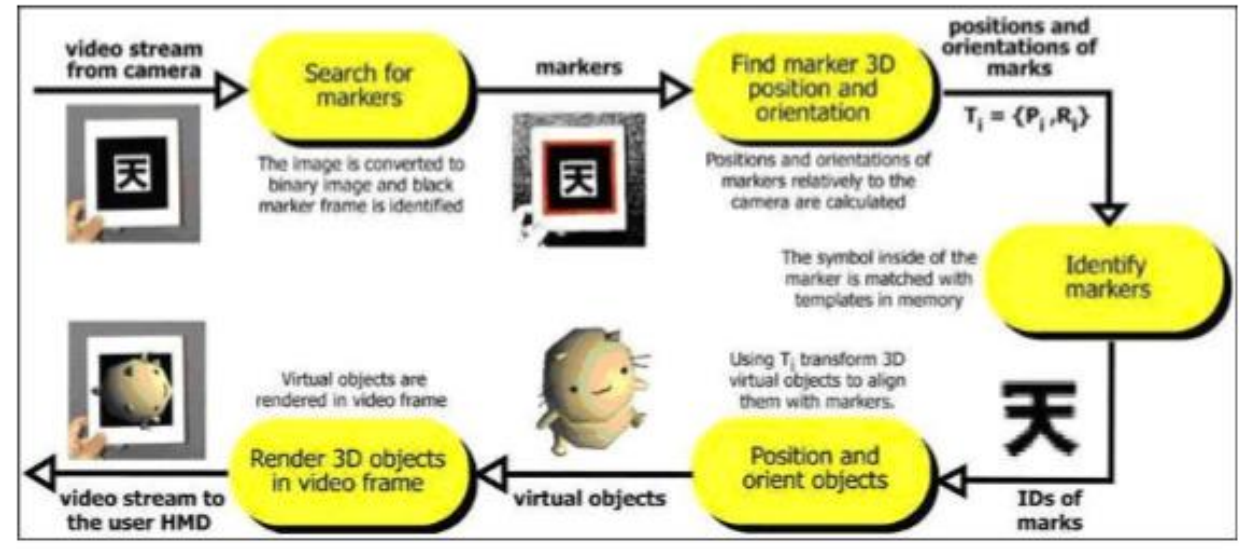

Gambar 1. Prinsip Kerja Augmented reality

Unity 3D adalah sebuah alat yang digunakan untuk membuat games, simulasi, dan bangunan arsitektur (Mahendra, 2016; Putri, et al., 2019). Unity dapat diterapkan untuk game PC dan Game online memakai unity browser. Pemrograman yang digunakan bervariasi, antara lain JavaScript, C\#, dan Boo. Unity adalah sebuah game multi platform yang dapat digunakan pada PC, Mac, Wii, iPhone, iPad, Android dan browser. Perizinan atau license dari Unity ada dua bentuk. Ada Unity dan Unity Pro. Versi Unity tersedia dalam bentuk gratis, sedang versi Unity Pro hanya dapat dibeli. Versi Unity pro ada dengan fitur bawaan seperti efek post processing dan render efek texture. Versi Unity merupakan yang gratis memperlihatkan aliran untuk game web dan layar splash untuk game yang berdiri sendiri. Unity dan Unity Pro menyediakan tutorial, isi, contoh project, wiki, dukungan melalui forum dan perbaruan kedepannya. Unity digunakan pada iPhone, iPod dan iPad operating system yang mana iOS ada sebagai add-ons pada Unity editor yang telah ada lisensinya, dengan cara yang sama juga pada Android (Mario, 2013).

Vuforia Qualcomm merupakan library yang digunakan sebagai pendukung adanya augmented reality pada Android (Karisman, 2019). Vuforia menganalisa gambar dengan menggunakan pendeteksi marker dan menghasilkan informasi 3D dari marker yang sudah dideteksi via API. Programmer juga dapat menggunakannya untuk membangun objek 3D virtual pada kamera. Vuforia mengijinkan pengembang untuk melakukan koneksi antara aplikasi yang sudah dibuat dengan library static 
contohnya libQCAR.a pada iOS atau libQCAR.so pada Android. Gambar 2 menjelaskan gambaran umum bagaimana proses pembangunan aplikasi mengunakan vuforia. User meng-upload gambar masukan unruk target yang ingin dilacak dan diregistrasikan. Kemudian mendownload sumber daya target yang di-bundel pada aplikasi. Pada proses ini sumber daya target yang didowload yaitu berupa library yang sudah di-bundel dengan aplikasi unity 3D.(Mario, 2013)

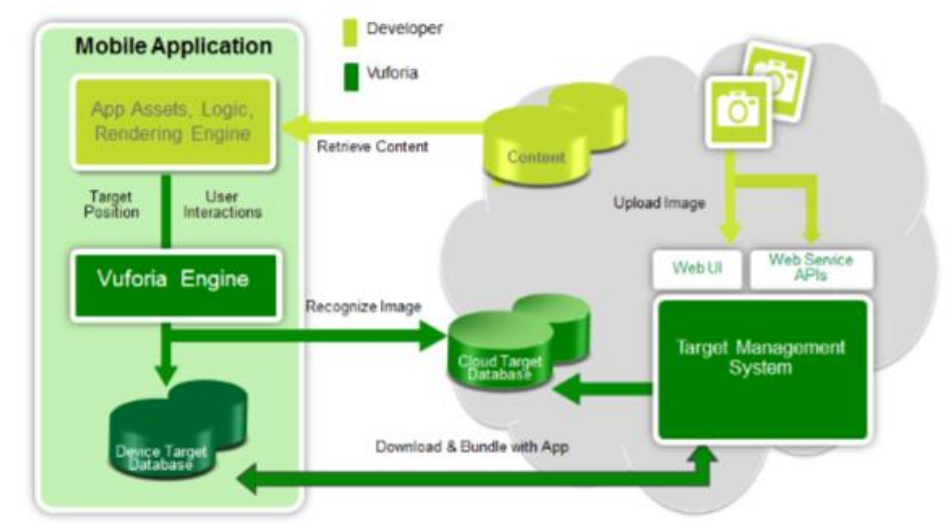

Gambar 2. proses pembangunan aplikasi mengunakan vuforia (Hynra, 2014)

Pada penelitian ini metode pengembangan sistem yang digunakan adalah metode waterfall. Penulis memilih menggunakan metode pengembangan sistem waterfall pada penelitian ini karena metode ini sederhana dan cocok digunakan untuk pengembangan perangkat lunak dengan spesifikasi yang tidak berubah ubah atau kebutuhan user sudah diketahui dengan jelas. Metode air terjun atau yang sering disebut metode waterfall sering dinamakan siklus hidup klasik (classic life cycle), dimana hal ini menggambarkan pendekatan yang sistematis dan juga berurutan pada pengembangan perangkat lunak, dimulai dengan spesifikasi kebutuhan pengguna lalu berlanjut melalui tahapan-tahapanyang meliputi meliputi: analisis, perancangan, implementasi, pengujian, penerapan program, dan pemeliharaan. Namun pada penelitian ini, penulis menggunakan metode Waterfall sampai tahap pengujian.

1. Analisis Kebutuhan

Pada tahap ini, penulis mengumpulkan data yang diperlukan dari berbagai sumber melalui metode studi kepustakaan. Penulis menggunakan jaringan internet untuk mencari bahan sebagai referensi dan buku yang berhubungan.

2. Perancangan

Tahap Perancangan merupakan proses multi langkah yang berfokus pada perancangan flowcart, struktur navigasi, sketsa dan model objek.

3. Implementasi

Pada tahap ini dilakukan implementasi dengan menggabungkan objek-objek yang telah dirancang dan dimodelkan

4. Pengujian

Proses pengujian berfokus pada logika internal sistem sehingga dapat memastikan bahwa sistem sesuai dengan proses bisnis yang telah dirancang, dan fokus pada eksternal fungsional, yaitu pengujian dilakukan untuk menemukan kesalahan-kesalahan serta memastikan bahwa input yang dibatasi akan memberikan hasil aktual sesuai dengan hasil yang dibutuhkan.

5. Evaluasi

Pada tahap ini dilakukan untuk melihat keberhasilan dari aplikasi yang dibangun dengan cara menyebarkan angket/ kuesioner.

\section{Metode Penelitian}

Metode penelitian yang digunakan adalah metode penelitian dan pengembangan atau Research and Development (R\&D) yaitu metode penelitian yang digunakan untuk menghasilkan produk tertentu dan menguji keefektifan produk tersebut (Sugiyono, 2015) .Penelitian R\&D ini menghasilkan produk berupa Media Pembelajaran Berbasis Augmented Reality. 
Desain penelitian yang digunakan mengacu pada langkah-langkah penelitian dan pengembangan yang telah dikembangkan oleh (Sugiyono, 2015) yaitu potensi dan masalah, pengumpulan data, desain produk, validasi desain, revisi desain, dan ujicoba produk (ujicoba terbatas).

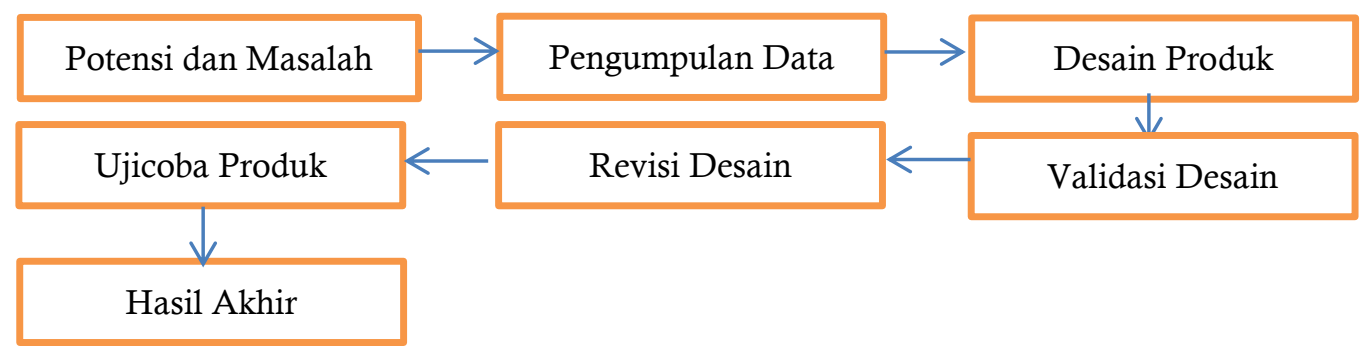

Gambar 3. Langkah-langkah Desain Penelitian

Berikut ini deskripsi dari masing-masing langkah-langkah yang disesuaikan dengan desain penelitian pengembangan video pembelajaran sebagai berikut: (1) Potensi dan masalah: dalam tahap ini dilakukan analisis potensi dan masalah dengan analisis kurikulum, analisis materi, dan analisis kebutuhan; (2) Pengumpulan data: perlu dikumpulkan berbagai informasi dan data yang dapat digunakan sebagai bahan dalam pembuatan produk Media Pembelajaran Berbasis Augmented Reality; (3) Desain produk: dalam pembuatan videosribe ini mengacu pada SK/ KD/ Indikator; (4) Validasi desain: proses kegiatan untuk menilai apakah rancangan produk ini telah memenuhi kriteria kelayakan atau belum; (5) Revisi produk: produk selanjutnya direvisi/ diperbaiki berdasarkan saran dan masukan yang diberikan oleh para ahli; (6) Uji coba produk (uji coba terbatas): agar mengetahui respon serta penilaian peserta didik tentang Pembelajaran Berbasis Augmented Reality ini; Hasil akhir: produk video pembelajaran dengan berbasis Berbasis Augmented Reality pada mata pelajaran bahasa inggris untuk kelas VI di Sekolah Dasar di Kabupaten Lebak. Pengumpulan data yang dilakukan dalam peneltian ini dengan menggunakan (1) angket: bertujuan untuk mengetahui validasi kelayakan produk yang digunakan di dalam kelas dan mengetahui respon peserta didik terhadap produk pengembangan tersebut. Angket diberikan kepada ahli materi, ahli media, ahli pendidikan, dan peserta didik; dan (2) Dokumentasi: untuk memperkuat data yang diperoleh dari hasil angket.

Teknik analisis data dilakukan untuk mendapatkan media pembelajaran yang layak digunakan serta memenuhi kriteria kevaliditas. Penilaian dari hasil uji ahli dilakukan berdasarkan data menggunakan skala Likert dengan skor 1, 2, 3, 4, 5.

Tabel 1. Aturan Pemberian Skor Validasi Ahli

\begin{tabular}{ccc}
\hline No & Kategori & Skor \\
\hline 1 & Sangat Layak & 5 \\
2 & Layak & 4 \\
3 & Cukup Layak & 3 \\
4 & Kurang Layak & 2 \\
5 & Tidak Layak & 1 \\
\hline \multicolumn{2}{c}{}
\end{tabular}

Hasil yang sudah diperoleh dalam bentuk persen diubah kembali menjadi bentuk kualitatif sesuai dengan aturan yang telah diuraikan untuk menentukan kategori kelayakan video pembelajaran. Hasil uji oleh ahli dapat dinyatakan layak apabila memenuhi minimal kategori yaitu layak dengan persentase pada tabel dibawah ini.

Tabel 2. Interpretasi Kategori Kelayakan Video Pembelajaran

\begin{tabular}{cc}
\hline Skor $(\%)$ & Kategori kelayakan \\
\hline $\mathrm{NP} \leq 20$ & Tidak layak \\
$20<\mathrm{NP} \leq 40$ & Kurang layak \\
$40<\mathrm{NP} \leq 60$ & Cukup layak \\
\hline
\end{tabular}




\begin{tabular}{cc}
$60<\mathrm{NP} \leq 80$ & Layak \\
$80<\mathrm{NP} \leq 100$ & Sangat layak \\
\hline & Sumber: (Riduwan, 2009)
\end{tabular}

Pada angket respon peserta didik terdiri dari pertanyaan positif dan negatif, angket tersebut berdasarkan daya menggunakan skala Likert dengan skor 1, 2, 3, 4 yang dapat dilihat pada tabel berikut ini:

Tabel 3. Aturan Pemberian Skor Respon Peserta Didik

\begin{tabular}{ccc}
\hline Pernyataan Sikap & Positif & Negatif \\
\hline Sangat Setuju & 4 & 1 \\
Setuju & 3 & 2 \\
Tidak Setuju & 2 & 3 \\
Sangat Tidak Setuju & 1 & 4 \\
\hline
\end{tabular}

Sumber: (Sugiyono, 2015)

Hasil uji coba terbatas terhadap video pembelajaran berbasis aplikasi Berbasis Augmented Reality yang dilakukan oleh peserta didik dapat dinyatakan dengan baik apabila memenuhi minimal kategori yaitu baik dengan persentase pada tabel dibawah ini.

Tabel 4. Interpretasi Kategori Respon Peserta Didik

\begin{tabular}{cc}
\hline Skor $(\%)$ & Kategori kelayakan \\
\hline $80<\mathrm{NP} \leq 100$ & Sangat Baik \\
$60<\mathrm{NP} \leq 80$ & Baik \\
$40<\mathrm{NP} \leq 60$ & Cukup \\
$20<\mathrm{NP} \leq 40$ & Kurang \\
$\mathrm{NP} \leq 20$ & Sangat Kurang \\
\hline \multicolumn{2}{c}{ Sumber: (Riduwan, 2009) }
\end{tabular}

\section{Hasil dan Pembahasan}

Hasil penelitian pada pengembangan video pembelajaran berbasis aplikasi Augmented Reality ini mengacu pada langkah-langkah yang telah dikembangkan oleh Sugiyono yaitu melakukan potensi dan masalah, pengumpulan data, desain produk, validasi desain, revisi desain, ujicoba produk.

Potensi dan masalah; tahap ini dilakukan analisis potensi dan masalah dengan (a) Analisis kurikulum: tahapan ini didapatkan hasil berupa analisis kurikulum yang mengacu pada Kurikulum Tingkat Satuan Pendidikan (KTSP) untuk kelas VI SD dengan mengidentifikasi standar kompentensi dan kompetensi dasar kemudian diuraikan menjadi indikator; (b) Analisis materi: Materi yang digunakan adalah materi benda-benda yang ada di sekitar pada Kurikulum Tingkat Satuan Pendidikan (KTSP), dan (c) Analisis kebutuhan: analisis kebutuhan pada materi benda-benda yang ada di sekitar di kelas VI menunjukan bahwa media pembelajaran yang sering digunakan guru masih berupa gambar dan menggunakan aplikasi powerpoint sehingga media pembelajaran berupa video pembelajaran berbasis aplikasi Augmented Reality tidak ditemukan pada pembelajaran IPS.

Pengumpulan data; peneliti mengumpulkan informasi mengenai perangkat pembelajaran dan referensi materi yang akan digunakan dalam media pembelajaran berupa video pembelajaran berbasis aplikasi Augmented Reality. Peneliti juga mengumpulkan data yang diperlukan untuk video pembelajaran berbasis aplikasi Augmented Reality berupa gambar, animasi, dan suara yang digunakan sebagai bahan untuk produk yang akan dikembangkan. Setelah informasi dan data terpilih, peneliti melakukan penyesuaian dengan materi dan gambar yang akan dijadikan video pembelajaran.

Untuk memudahkan alur program, peneliti membuat perancangan dalam bentuk flowcart aplikasi media pembelajaran berbasis Augmented Reality seperti pada gambar 3. 


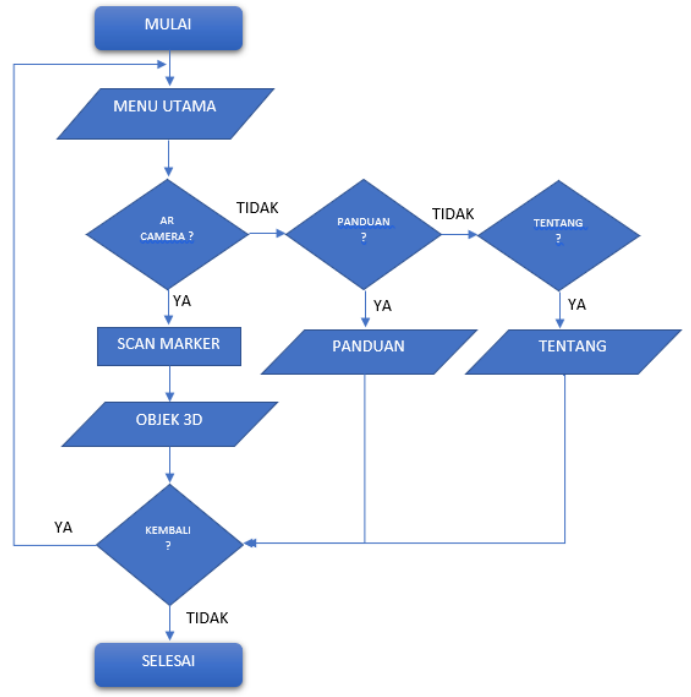

Gambar 4. Flowchart

Kemudian penulis membuat struktur navigasi yang dimana berisikan tentang alur informasi yang akan di tampilkan pada aplikasi media pembelajaran berbasis Augmented Reality seperti pada gambar 4.

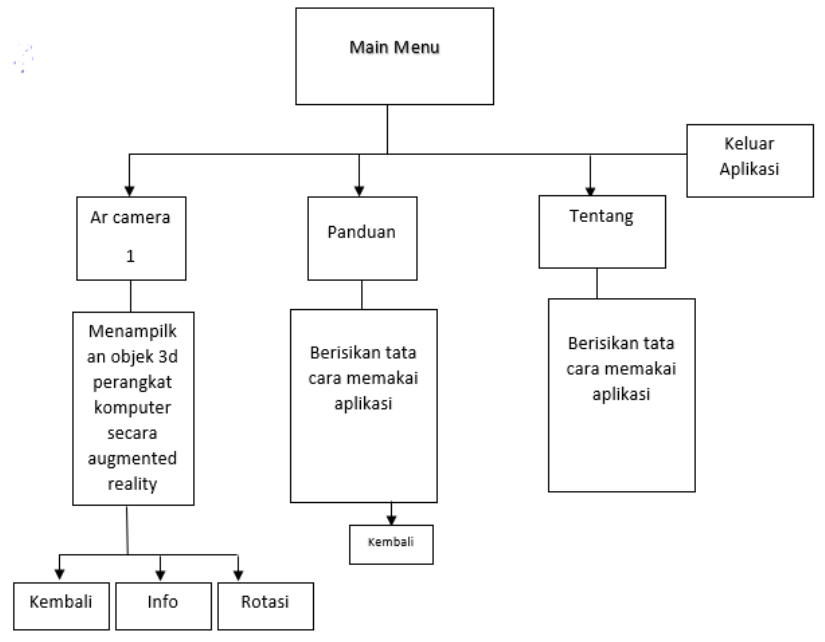

1. Implementasi

Gambar 5. Struktur Navigasi

Setelah dibuatkan perancangan aplikasi, kemudian tahap berikutnya adalah mengimplementasikan rancangan sudah dibuat kedalam bentuk program. Pembuatan program adalah proses implementasi dari perancangan/ alur bisnis menjadi sebuah program dengan menggunakan berbagai aplikasi dalam bahasa pemrograman. Hasil akhir dari tahap ini adalah sistem yang mempunyai fungsionalitas sesuai dengan yang diharapkan. Langka-langkah yang dilakukan pada proses ini yaitu:

1. persiapan asset, yaitu melakukan instalasi aplikasi Unity 3D sebagai software utama pada komputer yang akan digunakan untuk pembuatan program,

2. Pembuatan marker, yang nantinya akan berfungsi sebagai penanda objek virtual yang akan dipasang,

3. Mengunggah marker yang telah ke Vuforia untuk dilakukan verifikasi,

4. Membuat proyek baru di Unity 3D, seperti pada Gambar 5 di bawah ini. 


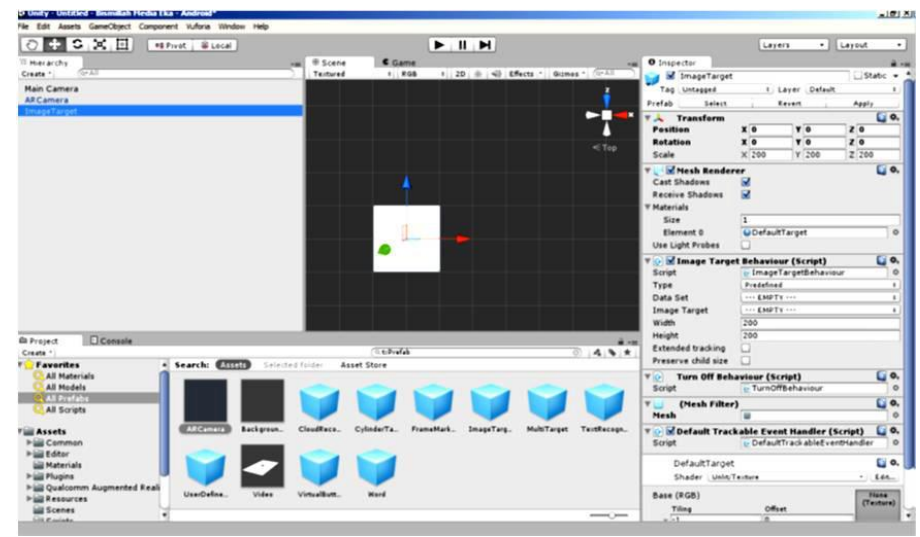

Gambar 6. Tampilan projek Unity3D

Kemudian mengimplementasikan rancangan yang sudah dibuat sebelumnya menjadi sebuah program. Diawali dengan pembuatan menu utama yang terlihat pada Gambar 6, sampai dengan implementasi objek terhadap marker yang sudah dirancang yang terlihat pada tampilan Gambar 7 . Action diberikan pada tiap tombol berdasarkan rancangan struktur navigasi yang telah dirancang sebelumnya. Proses Pemrograman terus dilakukan sampai seluruh disain dapat dijalankan.

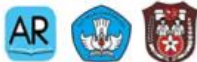

\section{PENELITIAN PDP}

PENGembangan media pembelajaran BERBASIS TEKNOLOGI APLIKASI AUGMNETED

REALITY DALAM MENINGKATKAN PROSES PENGAJARAN

SISWA SEKOLAH DASAR DI KABUPATEN LEBAK.
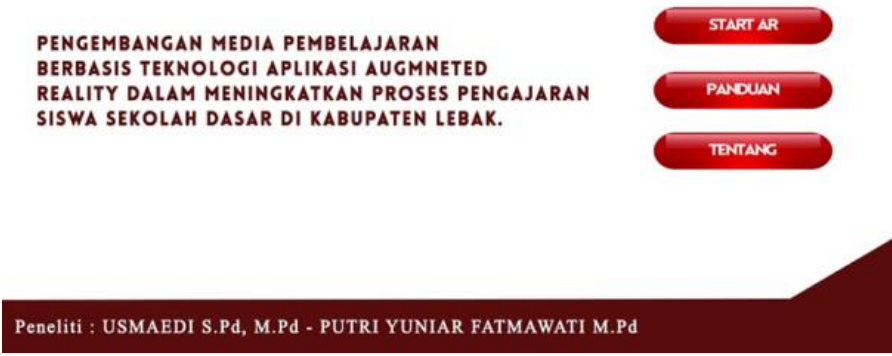

Gambar 7. Tampilan Menu Utama

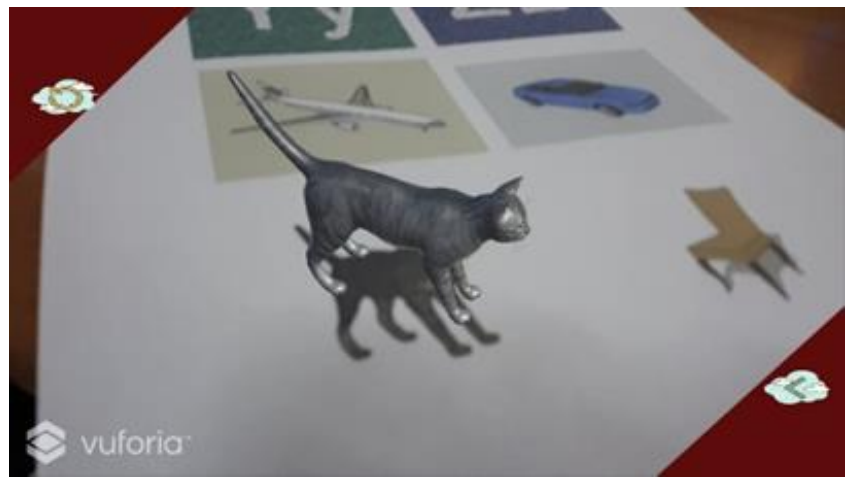

Gambar 8. Tampilan Marker dan Objek $A R$

\section{Pengujian}

Tahap selanjutnya yaitu pengujian aplikasi yang telah selesai dilakukan pemrograman. Metode pengujian yang digunakan dalam penelitian ini adalah metode black box testing. Black box Testing merupakan jenis pengujian yang dilakukan untuk mengamati hasil dari eksekusi pada software yang diuji. Hasil pengujian akan menunjukan kesesuaian antara output program dengan rancangan program. Uji coba juga dilakukan dengan melakukan pemindaian marker AR.

3. Rencana Pengujian 
Setelah Aplikasi sudah berjalan untuk pertama kali ada juga hal yang akan di uji melalui pengujian black box berupa table yang bisa di lihat pada Tabel 1 di bawah ini.

Tabel 5. Rencana Pengujian

\begin{tabular}{ll}
\hline Requirement Yang di uji & \multicolumn{1}{c}{ Point uji } \\
\hline Menu Utama & $\begin{array}{l}\text { Melakukan pengujian pada tombol - tombol AR Camera, } \\
\text { Panduan Aplikasi dan Tentang Aplikasi. Yang akan } \\
\text { mengarahkan ke masing-masing halaman menu. }\end{array}$ \\
\hline Menu AR Camera & $\begin{array}{l}\text { Melakukan pengujian pada halaman menu Camera AR. } \\
\text { Pengujian dilakukan dengan cara melakukan pindai/ scan } \\
\text { terhadap marker yang nantinya akan memunculkan objek } \\
\text { virtual. }\end{array}$ \\
\hline Menu Panduan Aplikasi & $\begin{array}{l}\text { Melakaukan pengujian menu Panduan Aplikasi yang kontennya } \\
\text { berisi halaman petunjuk penggunaan aplikasi. }\end{array}$ \\
\hline Menu Tentang Aplikasi & $\begin{array}{l}\text { Melakaukan pengujian menu Tentang Aplikasi yang kontennya } \\
\text { berisi halaman tentang pengembang aplikasi. }\end{array}$ \\
\hline
\end{tabular}

4. Hasil Pengujian

Berisikan tabel hasil dari pengujian yang sudah di lakukan pada rencana pengujian. Akan di tampilkan pada Tabel 2 berikut:

Tabel 6. Hasil Pengujian

\begin{tabular}{|c|c|c|c|}
\hline Test Case & Skenario Uji & Hasil yang diharapkan & Hasil Uji \\
\hline Menu Utama & $\begin{array}{l}\text { Melakukan pengujian } \\
\text { pada tombol-tombol } \\
\text { menu utama. }\end{array}$ & $\begin{array}{l}\text { Masing-masing tombol menu } \\
\text { mengarahkan aplikasi sesuai } \\
\text { dengan halaman yang telah } \\
\text { dirancang. }\end{array}$ & $\begin{array}{l}{[\sqrt{ }] \text { sesuai }} \\
{[\quad] \text { Tidak }}\end{array}$ \\
\hline Menu AR & Melakukan pindai/scan & Ketika dilakukan pindai AR Camera & {$[\sqrt{ }]$ sesuai } \\
\hline Camera & $\begin{array}{l}\text { AR Camera terhadap } \\
\text { marker objek. }\end{array}$ & $\begin{array}{l}\text { pada marker, maka akan muncul } \\
\text { objek virtual yang sesuai. }\end{array}$ & [ ] Tidak \\
\hline Menu Panduan & Melihat kesesuaian & Konten menu sesuai dan tombol & {$[\sqrt{ }]$ sesuai } \\
\hline Aplikasi & $\begin{array}{l}\text { konten menu dan } \\
\text { menguji tombol } \\
\text { kembali ke menu } \\
\text { utama. }\end{array}$ & $\begin{array}{l}\text { kembali dapat digunakan untuk } \\
\text { kembali ke menu utama }\end{array}$ & [ ] Tidak \\
\hline $\begin{array}{l}\text { Menu Tentang } \\
\text { Aplikasi }\end{array}$ & $\begin{array}{l}\text { Melihat kesesuaian } \\
\text { konten menu dan } \\
\text { menguji tombol } \\
\text { kembali ke menu } \\
\text { utama. }\end{array}$ & $\begin{array}{l}\text { Konten menu sesuai dan tombol } \\
\text { kembali dapat digunakan untuk } \\
\text { kembali ke menu utama }\end{array}$ & $\begin{array}{l}{[\sqrt{ }] \text { sesuai }} \\
{[\quad] \text { Tidak }}\end{array}$ \\
\hline
\end{tabular}

5. Evaluasi

Setelah dilakukan uji coba aplikasi, kemudian tahap selanjutnya yaitu dilakuka evaluasi dengan cara melakukan survey dengan metode pembagian angket atau kuesioner kepada responden. Adapun responden yang dipilih adalah siswa Sekolah Dasar dengan jumlah 39 responden.

Pada kuesioner aplikasi media pembelajaran in, ada 3 poin poin penilaian yang dijadikan berbagai pertanyaan yang diberikan kepada responden, yaitu:

1. Desain : Tampilan Aplikasi menarik, Tampilan Objek Iaugmented Reality seperti bentuk aslinya, Saturasi dan kontras warna baik.

2. Informasi : Penyampaian informasi yang jelas, visualisasi objek yang menarik, membantu menjelaskan materi pada mata pelajaran Bahasa Inggris secara visual, media pembelajaran yang menarik.

3. Kemudahan Penggunaan : Aplikasi mudah di gunakan. Fitur - fitur mudah di gunakan, Aplikasi berjalan lancar, Cara penggunaan mudah di mengerti. 
Dari kuesioner yang di ajukan keseluruhan responden point yang di dapat, mendapatkan hasil seperti berikut :

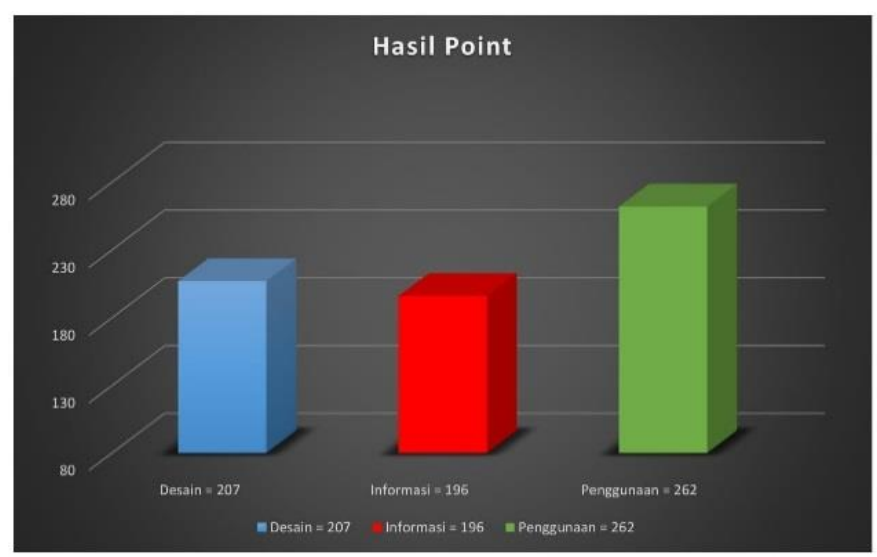

Gambar 8

Hasil Point Kuesioner

Keterangan Gambar 8:

1. Pertanyaan Desain mendapatkan point : 207 (Tercapai)

2. Pertanyaan tingkat penyampaian informasi Informasi mendapatkan point : 196 (Tercapai)

3. Pertanyaan tingkat kemudahaan penggunaan aplikasi mendapatkan point : 262 (Tercapai).

\section{Kesimpulan}

Berdasarkan hasil pengujian aplikasi dengan menggunakan metode black box, dapat disimpulkan bahwa aplikasi dapat diimplementasikan menjadi aplikasi media pembelajaran berbasis Augmented Reality pada mata pelajaran Bahasa Inggris Sekolah Dasar berjalan baik. Dan berdasarkan hasil survey dengan menggunakan metode penyebaran angket siswa terhadap aplikasi media pembelajaran berbasis Augmented Reality pada mata pelajaran Bahasa Inggris, dapat disimpulkan bahwa aplikasi pembelajaran ini sangat interaktif dan mudah digunakan, sehingga dengan mengaplikasikan aplikasi media pembelajaran ini dapat membantu meningkatkan proses pengajaran yang lebih menarik dan mudah dipahami.

\section{Daftar Pustaka}

Adami, F. Z., \& Budihartanti, C. (2016). Penerapan Teknologi Augmented Reality pada Media Pembelajaran Sistem Pencernaan Berbasis Android. Jumal Teknik Komputer, 2(1), 122131.

Ginting, S. L. B., Ginting, Y. R., \& Aditama, W. (2017). Augmented Reality Sebagai Media Pembelajaran Stimulasi Bayi Menggunakan Metode Marker Berbasis Android. Jurnal Manajemen Informatika (JAMIKA), 7(1).

Hamalik, O. (2001). Perencanaan Pengajaran Pendekatan Sistem. Bandung: Bumi Aksara.

Hynra. (2014). Unity tutorial vuforia simple image target. Unity Tutorial. Retrieved from https://hynra.com/post/unity-tutorial-vuforia-simple-image-target.

Karisman, A. (2019). Aplikasi Media Pembelajaran Augmented Reality Pada Perangkat Keras Komputer Berbasis Android. JATISI (Jurnal Teknik Informatika dan Sistem Informasi), 6(1), 18-30.

Laksono, D. S. (2018). Penerapan Teknologi Augmented Reality Pada Android Sebagai Media Pembelajaran Huruf Aksara Jawa Bagi Anak Didik Setingkat SLTP. Ubiquitous: Computers and its Applications Journal, 1(1), 67-80. 
Laswi, A. S., \& Andryanto, A. (2018). Implementasi Augmented Reality Pada Museum Batara Guru Kompleks Istana Langkanae Luwu. ILKOM Jurnal Ilmiah, 10(2), 144-151.

Mahendra, I. B. M. (2016). Implementasi Augmented Reality (AR) Menggunakan Unity 3D Dan Vuporia Sdk. Dari https://ojs. unud. ac. id/index. php/jik/article/view/26341.

Mario, F. (2013). Membuat Aplikasi Android Augmented Reality Menggunakan vuforia sdk dan unity. Surakarta: AR Online.

Putri, N. D., Anra, H., \& Perwitasari, A. (2019). Aplikasi Augmented Reality Pengenalan Barang Sejarah pada Istana Kadriah Kota Pontianak. JUSTIN (Jurnal Sistem dan Teknologi Informasi), 7(1), 7-12.

Riduwan. (2009). Dasar-Dasar Statistik. Bandung: Alfabeta.

Sugiyono. (2015). Metode Penelitian Pendekatan; Pendekatan Kuantitatif Kualitatif, dan R\&D. Bandung: Alfabeta.

Suprapto, Safaruddin, Al Ikhsan. (2018). Implementasi Augmented Reality Labs Tour Prodi TI dengan metode Marker Based Tracking berbasis Android. INOV A-TIF, 1(1).

Suciliyana, Y. (2020). Augmented Reality Sebagai Media Pendidikan Kesehatan Untuk Anak Usia Sekolah. Jurnal Surya Muda | Jurnal STIKES Mubammadiyah Kendal, 2(1), 39-53. 